quadruplet at $6.21 \tau\left(\mathrm{J}=6 \mathrm{c}\right.$.p.s., $\left.\mathrm{CH}_{3}-\mathrm{CH}(\mathrm{OH})-\mathrm{C} \ll\right)$, which was subject to conversion into the ketone (VII), $\mathrm{C}_{13} \mathrm{H}_{20} \mathrm{O}, \mathrm{m} . \mathrm{p} .40 .5^{\circ}$, IR band $(\mathrm{KBr})$ at $1730 \mathrm{~cm}^{-1}$ (cyclopentanone), ORD: $a+153$. Acetylation of the $\operatorname{kotol}(\mathrm{II} ; \mathrm{R}=\mathrm{H})$ furnished the stable acetate $\left(\mathrm{II} ; \mathrm{R}=\mathrm{COCH}_{3}\right.$ ) whose optical rotatory dispersion curve shows a positive Cotton effect $(a+48)$; the $\mathrm{C}-5$ substituent being consequently $\beta$-oriented. ${ }^{4)}$ The $c i$ s relationship of the $\mathrm{C}-3$ and $\mathrm{C}-5$ substituents was further confirmed by the presence of an intramolecularly-hydrogenbonded hydroxyl band at $3535 \mathrm{~cm}^{-1}$ in the infrared $\left(\mathrm{CCl}_{4}\right)$ of the diol $(\mathrm{V})$. I. $* 2$

Whereupon the absolute stereochemistry of cyperolone is represented by formula curves.

The authors would like to present their thanks to Prof. K. Nakanishi, this University, for the ORD

\author{
Pharmaceutical Institute, \\ Tohoku University \\ School of Medicine, \\ Kita-4-bancho, Sendai
}

Received July 9, 1966

\begin{tabular}{|c|c|}
\hline hi Hikino & (ヒキノヒロシ) \\
\hline Keitaro Aota & (青田恵太郎) \\
\hline Yukio Maebayashi & (前 林 行 雄) \\
\hline Tsunematsu Takemoto & （竹本常 松 \\
\hline
\end{tabular}

*2 The authors propose the name cyperane, with the numbering shown, for the skeleton of cyperolone.

4) cf. W. Klyne : Tetrahedron, 13, 29 (1961).

\title{
Synthesis of Cyperolone
}

The sesquiterpenic keto-alcohol cyperolone, $\mathrm{C}_{15} \mathrm{H}_{24} \mathrm{O}_{2}$, was recently isolated from the rhizome of nutgrass (Cyperus rotundus LiNNÉ) by the authors who proposed the stereostructure I based on the chemical and physico-chemical evidence obtained. ${ }^{1)}$ A synthesis of cyperolone by a method which confirms both structure and absolute stereochemistry is now presented.

Biogenetic considerations suggest that the carbon skeleton of cyperolone is derived from an intermediate having the structure $A$, by some version of the "pinacol-pinacolone" rearrangement as shown in Chart 1 . This rearrangement must be useful in the synthetic work, which has been performed as follows.

$(+)-\alpha$-Cyperone $(\mathrm{I})$ was reduced with lithium aluminum hydride to give eudesma-4,11-dien-3 $\beta$-ol (III) (quantitative yield), $[\alpha]_{\mathrm{D}}+10.9^{\circ}$, IR band (liquid) at $3390 \mathrm{~cm}^{-1}$ (hydroxy1).*1 The orientation of the hydroxyl group is shown by the nuclear magnetic resonance (NMR)

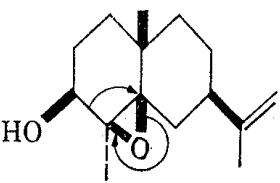

A

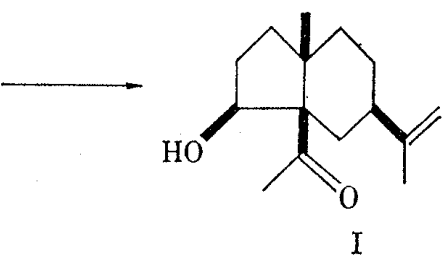

Chart 1. signal of the $\mathrm{C}-3$ hydrogen at $6.13 \tau$ as a broad peak (band width at half height: 15 c.p.s.). Epoxidation of the alcohol (III) with 1 mole of perbenzoic acid produced a single mono-epoxide, $4 \beta, 5 \beta$-oxido-eudesm-

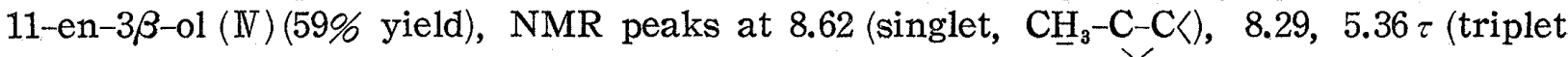

*1 Specific rotations were measured in $\mathrm{CHCl}_{3}$ solution. NMR spectra were determined at $60 \mathrm{Mc}$. in $\mathrm{CCl}_{4}$ solution against internal $\left(\mathrm{CH}_{3}\right)_{4} \mathrm{Si}$.

1) H. Hikino, K. Aota, Y. Maebayashi, T. Takemoto : This Bulletin, 14, 1439 (1966), and the experimental details to be published. 
and quartet, $\mathrm{J}=1$ c.p.s., $\mathrm{CH}_{3}-\mathrm{C}=\mathrm{CH}_{2}$ ), together with a diepoxide (V). The configuration of the epoxide ring was indicated by a positive Cotton curve $e^{2)}(a+75)$ of the oxidation product (VII), vide infra.

Treatment of the epoxide $(\mathbb{N})$ with boron trifluoride in benzene solution at room temperature for $3 \mathrm{~min}$. yielded a mixture of products in which the only ketol was not the desired one, cyperolone (I), but eudesm-11-en-3-on-5 $\beta$-ol (V), m.p. 138 $139^{\circ}$, whose structure was deduced from the spectral evidence: IR bands (KBr) at 3413 (hydroxyl), $1718 \mathrm{~cm}^{-1}$ (cyclohexanone), NMR peaks at 8.99, $7.02 \tau$ (doublet and quartet, $\mathrm{J}=7 \mathrm{c} . \mathrm{p} . \mathrm{s}$., $\left.-\mathrm{CO}-\left(\mathrm{CH}_{3}\right) \mathrm{CH}-\mathrm{C}<\mathrm{OH}\right)$.

The epoxy-alcohol $(\mathbb{N})$ was, therefore, oxidized with chromium trioxide-pyridine complex to furnish $4 \beta, 5 \beta$-oxido-eudesm-11-en-3-one (VII) (88\% yield), IR bands (liquid) at 1712 (cyclohexanone), $889 \mathrm{~cm}^{-1}$ (vinylidene). The keto-epoxide (VII) was isomerized with boron trifluoride in benzene solution at room temperature for $5 \mathrm{~min}$. to cyper-11-ene3,4-dione (VII) (25\% yield) having infrared and NMR spectra identical with those of the dione $^{1)}$ obtained from cyperolone by chromic acid oxidation. Since the epoxy-ring has the $\beta$-configuration in the epoxide (VI), the newly formed acetyl group in the dione (VII) must also be $\beta$-oriented on mechanistic grounds being compatible with the previous

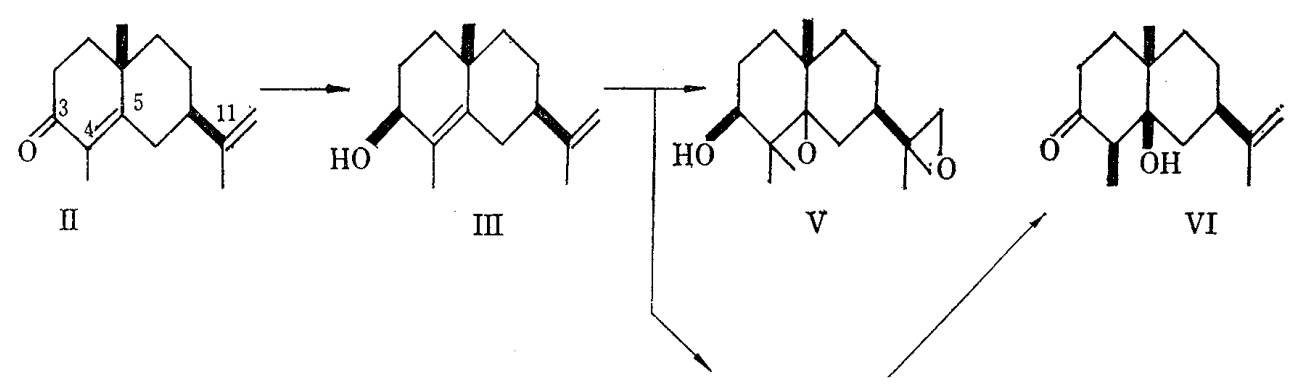

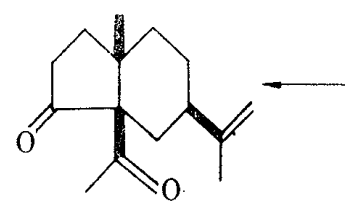

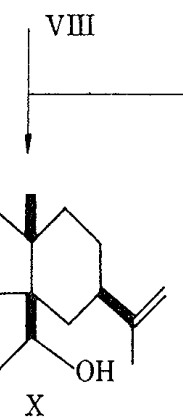

IV
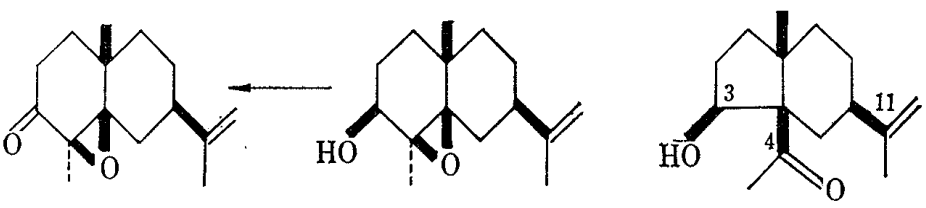

I
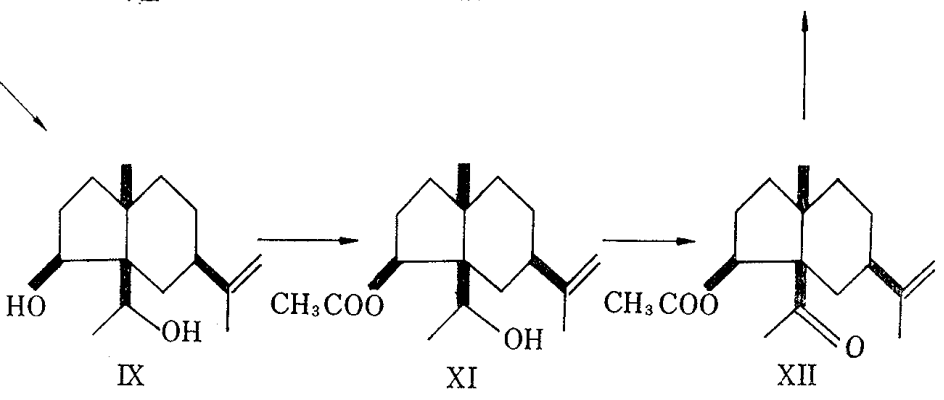

Chart 2.

conclusion. ${ }^{1)}$ Reduction of the dione (VII) with lithium aluminum hydride led to cyper-

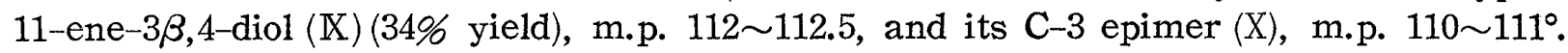
The former was identified as the diol ${ }^{11}$ prepared by reduction of cyperolone. On partial

2) C. Djerassi, W. Klyne, T. Norin, G. Ohloff, E. Klein : Tetrahedron, 21, 163 (1965). 
acetylation, the diol $(\mathrm{X})$ yielded, together with its diacetate, $3 \beta$-acetoxy-cyper-11-en-4ol (XI) (49\% yield), IR bands (liquid) at 3521 (hydroxyl), $1730 \mathrm{~cm}^{-1}$ (acetoxyl), NMR peaks at $8.61,6.35$ (doublet and quartet, $\mathrm{J}=7$ c.p.s., $\mathrm{CH}_{3}-\mathrm{CH}(\mathrm{OH})-\mathrm{C} \ll$ ), $4.45 \tau$ (quartet, $\mathrm{J}_{1}=7$, $\mathrm{J}_{2}=9$ c.p.s., $\mathrm{H}-\mathrm{C}<\mathrm{OCOCH}_{3}$ ), which was oxidized with chromic acid to $3 \beta$-acetoxy-cyper11-en-4-one (XI) (88\% yield), $[\alpha]_{\mathrm{D}}+62.1^{\circ}$, IR bands (liquid) at 1742 (acetoxyl), $1701 \mathrm{~cm}^{-1}$ (acety1), NMR peak at $7.96 \tau\left(\mathrm{CH}_{3}-\mathrm{CO}-\right)$, identified as cyperolone acetate. Although cyperolone, a $\beta$-ketol, is sensitive to alkali, hydrolysis of the ketol acetate (XII) using 1 mole of sodium hydroxide in ethanol furnished synthetic cyperolone (I) (91\% yield), m.p. $40 \sim 41^{\circ}$ (monohydrate), identical in every respect with the natural substance. ${ }^{1)}$

The authors are grateful to Prof. K. Nakanishi, this University, for the ORD curve.

\author{
Pharmaceutical Institute, \\ Tohoku University \\ School of Medicine, \\ Kita-4-bancho, Sendai
}

Received July 9, 1966

\author{
Hiroshi Hikino （ヒキノヒロシ） \\ Norio Suzuki （鈴木範 夫) \\ Tsunematsu Takemoto (竹本常松)
}

\section{Structure of Innovanamine}

A new glycoside, innovanamine, was isolated from the fallen leaves of Evodiopanax innovans NakaI. The methanol extract of powdered leaves $(17 \mathrm{~kg}$.$) was concentrated,$ equivolume of water was added, and the resinous substance was removed. The aqueous solution was saturated with basic lead acetate, the precipitate formed was filtered off, excess of ammonia was added, and the solution filtered. The final aqueous solution was concentrated in vacuo to $3 \mathrm{~L}$. after removing lead ion with hydrogen sulfide and standing over night. The crystalline precipitate was collected $(386 \mathrm{~g}$.$) and recrystal-$ lised from hot water to colorless prisms, m.p. $116 \sim 118^{\circ},[\alpha]_{\mathrm{D}}^{2 \mathrm{~s}}-61.6^{\circ}\left(\mathrm{c}=10, \mathrm{H}_{2} \mathrm{O}\right)$; NMR (p.p.m.), $\left(\mathrm{D}_{2} \mathrm{O}\right): 2.47$ (singlet) $\mathrm{CH}_{3}, 3.51,3.85,4.82$ (multiplets), sugar hydrogen, 6.58, 7.74 (doublets, $\mathrm{J}=7$ c.p.s.) aromatic hydrogen (physical constants were determined with the hydrated substance). Anal. Calcd. for $\mathrm{C}_{12} \mathrm{H}_{17} \mathrm{O}_{7} \mathrm{~N} \cdot 2 \mathrm{H}_{2} \mathrm{O}: \mathrm{C}, 44.58 ; \mathrm{H}, 6.59$. Found: C, 44.67; H, 6.96. for $\mathrm{C}_{12} \mathrm{H}_{17} \mathrm{O}_{7} \mathrm{~N}: \mathrm{N}, 4.88$; O, 38.99; mol. wt., 287. Found: $\mathrm{N}, 4.85$; O, 39.11; mol. wt., 310 .

Four g. of innovanamine was dissolved in $8 \%$ hydrochloric acid in methanol and heated on steam bath for 3 hours. The solution was concentrated in vacuo. When cooled, colorless prisms were obtained, which were recrystallised from a mixture of ethyl acetate and methanol, m.p. $185^{\circ}$. Anal. Calcd. for $\mathrm{C}_{6} \mathrm{H}_{7} \mathrm{O}_{2} \mathrm{~N} \cdot \mathrm{HCl}(\mathrm{II}): \mathrm{Cl}, 21.94$. Found: $\mathrm{Cl}, 21.37$. The free base was recrystallised from hot water, m.p. 293 294. Anal. Calcd. for $\mathrm{C}_{6} \mathrm{H}_{7} \mathrm{O}_{2} \mathrm{~N}: \mathrm{C}, 57.59 ; \mathrm{H}, 5.64 ; \mathrm{N}, 11.20$. Found: C, 58.01; H, 5.74; N, 10.97. The latter was identical with synthesized 2-methyl-3-hydroxy-4(1H)pyridone (III). ${ }^{1)}$ The mother liquor was concentrated to dryness in vacuo, carbohydrate components were examined by paper chromatography, and glucose was detected. Thus, the structure of innovanamine must be 2-methyl-3-glucosyloxy-4 $(1 H)$ pyridone (I). The glycoside linkage is $\beta$, because I was hydrolysed easily with emulsin.

1) A. Peratoner, A. Tamburello : Chem. Zentr. 1905, II, 680; B. E. Fisher, J. E. Hodge : J. Org. Chem., 29, 776 (1964). 